\title{
Errant survey draws fire
}

\section{Washington}

A BITTER dispute between two US science publishers took a bizzare turn this month when it was revealed that one had been surveying its customers under the letterhead of an unrelated foundation.

Last month Gordon and Breach Science Publishers, Inc. sent surveys to university libraries on the stationery of the Londonbased Foundation for International Cooperation - apparently without the foundation's prior approval. Among the 19 question included in the surveys were several that asked if the libraries had cancelled subscriptions as a result of an article in the July 1988 Physics Today that ranked physics journals by a ratio of their cost and impact.

The original Physics Today article put Gordon and Breach at the bottom of a list of 24 publishers. Charging "unfair comparative ranking", Gordon and Breach then sued the American Institute of Physics (AIP) and the American Physical Society - the organizations that publish Physics Today and the Bulletin of the American Physical Society - as well as the article's author, Henry Barschall, a retired professor of physics at the University of Wisconsin in Madison (see Nature 341, 28 September 1989).

Despite the questionable circumstances surrounding the distribution of the library survey, Frank Forrest, a spokesman for the company, says results from it could potentially be used as evidence in court to prove that Gordon and Breach was indeed damaged by the article in Physics Today.

The foundation disclaimed any knowledge of the survey when librarians brought it to the attention of the Association of Research Libraries and the Chroni- cle of Higher Education earlier this month. Gordon and Breach sales director Christopher Schneider says the use of the letterhead and the signature of Maurice Levy, the foundation's director, without permission was due to secretarial error. He says that Martin Gordon, chairman of the publishing company, is on the foundation's board and apparently gave the go-ahead before checking with officials. "The survey may have gone out a little prematurely," Schneider says.

Despite the imbrogolio, Forrest says that an agreement has subsequently been reached with the foundation to begin a project - of which the survey will be part - on the methodology of price-comparison studies and the importance of journal prices in purchasing decisions. The study will be for "market research purposes".

The publishing firm has already received dozens of survey responses from libraries, but no results have been released.

Four lawsuits against Physics Today's publishers have been filed by Gordon and Breach in three countries - France, West Germany and Switzerland - that have laws against "comparative advertising" (the United States does not). A Swiss court has thrown out one claim for being filed in the wrong court, although the others are still pending. AIP lawyer Richard Meserve says the suit appears to be "nuisance" litigation, intended to discourage comparative rankings such as the Physics Today article. He points out that even if Gordon and Breach won its suits, it would only be entitled to damages in those countries in which they have been filed, which would account for a very small proportion of Gordon and Breach sales.

\section{G. Christopher Anderson}

UK researchers to establish defence fund London

BRITISH scientists involved in experiments on animals may soon be able to receive help with legal fees to fight libel actions against animal rights groups or the press. The Research Defence Society (RDS) has set up a legal defence fund, which its director, Mark Matfield, hopes will "deter antivivisection activists from mounting campaigns against individual medical researchers". Matfield believes the fund will reach at least $£ 100,000$, and expects most contributions to come from scientific and learned societies.

The fund has been welcomed by scientists involved in work with animals. Nick Wright, associate director of clinical science with the Imperial Cancer Research Fund (ICRF) expects the defence fund to be called upon "quite often" and says it will be particularly valuable to researchers attacked in "protracted press campaigns". Wright says that the ICRF would pay legal fees if one of its researchers was libelled, but many scientists do not have this protection.

Professor Colin Blakemore of the University of Oxford, himself the victim of vilification in the national press, thinks the defence fund will act as a deterrent against libel. But he says that the fund is only the first step in the fight against the escalating attacks on researchers by animal rights groups.

Blakemore believes that recent press campaigns against animal researchers might have been curtailed if "appropriate organizations" (research councils, medical charities and scientific societies) had stepped forward to explain the value of research involving animals. Peter Aldhous

AGRICULTURAL RESEARCH

\section{Dismay at AFRC insect unit}

\section{London}

Restructuring at the Agricultural and Food Research Council's (AFRC) Unit of Insect Neurophysiology and Pharmacology at the University of Cambridge will lead to 8 redundancies later this year. A review of the unit's activities was expected, following the death of its director, John Treherne, last year, but some researchers in the field are surprised at the dismissal of scientists with an international reputation. One of the sacked researchers, Simon Madrell, is a Fellow of the Royal Society, widely regarded as a productive scientist with an excellent publication record.

The redundancies are all the more surprising, given that the unit is to focus its future research on the molecular basis of interactions between cells in insects. Both Madrell, and another of the dismissed scientists, Helen Skaer, have worked in this area.
PeterAldhous 